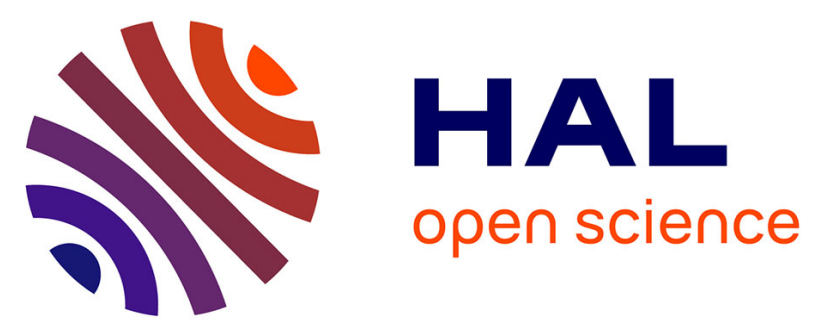

\title{
Dip-coated La2Ti2O7 as a buffer layer for growth of Bi3.25La0.75Ti3O12 films with enhanced ( $\left.\begin{array}{lll}0 & 1 & 1\end{array}\right)$ orientation
}

C.E. Liu, Mireille Richard-Plouet, Marie-Paule Besland, David Albertini, C. Estournes, Luc Brohan

\section{To cite this version:}

C.E. Liu, Mireille Richard-Plouet, Marie-Paule Besland, David Albertini, C. Estournes, et al.. Dip-coated La2Ti2O7 as a buffer layer for growth of Bi3.25La0.75Ti3O12 films with enhanced ( $\left.\begin{array}{lll}0 & 1 & 1\end{array}\right)$ orientation. Journal of the European Ceramic Society, 2009, 29 (10), pp.1977-1985. 10.1016/j.jeurceramsoc.2008.12.003 . hal-00432275

\section{HAL Id: hal-00432275 https://hal.science/hal-00432275}

Submitted on 10 Feb 2022

HAL is a multi-disciplinary open access archive for the deposit and dissemination of scientific research documents, whether they are published or not. The documents may come from teaching and research institutions in France or abroad, or from public or private research centers.
L'archive ouverte pluridisciplinaire HAL, est destinée au dépôt et à la diffusion de documents scientifiques de niveau recherche, publiés ou non, émanant des établissements d'enseignement et de recherche français ou étrangers, des laboratoires publics ou privés. 


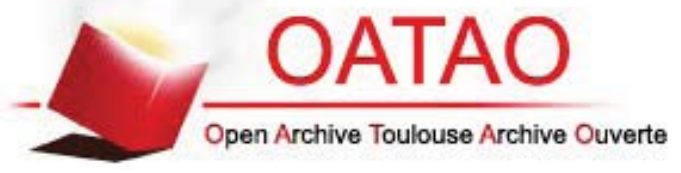

\section{Open Archive Toulouse Archive Ouverte (OATAO)}

OATAO is an open access repository that collects the work of Toulouse researchers and makes it freely available over the web where possible.

This is an author-deposited version published in: http://oatao.univ-toulouse.fr/ Eprints ID: 3984

To link to this article: doi:10.1016/j.jeurceramsoc.2008.12.003

URL: http://dx.doi.org/10.1016/j.jeurceramsoc.2008.12.003

To cite this version: Liu, Chia-Erh and Richard-Plouet, Mireille and Besland, Marie-Paule and Albertini, David and Estournès, Claude and Brohan, Luc ( 2009) Dip-coated La2Ti2O7 as a buffer layer for growth of Bi3.25La0.75Ti3O12 films with enhanced (0 11 1) orientation. Journal of the European Ceramic Society, vol. 29 ( $\left.\mathrm{n}^{\circ} 10\right)$. 1977-1985 . ISSN 0955-2219

Any correspondence concerning this service should be sent to the repository administrator: staff-oatao@inp-toulouse.fr 


\title{
Dip-coated $\mathrm{La}_{2} \mathrm{Ti}_{2} \mathrm{O}_{7}$ as a buffer layer for growth of $\mathrm{Bi}_{3.25} \mathrm{La}_{0.75} \mathrm{Ti}_{3} \mathrm{O}_{12}$ films with enhanced ( $\left.\begin{array}{llll}0 & 1 & 1\end{array}\right)$ orientation
}

\author{
Chia-Erh Liu ${ }^{\text {a }}$, Mireille Richard-Plouet ${ }^{\mathrm{a}, *}$, Marie-Paule Besland ${ }^{\mathrm{a}}$, David Albertini ${ }^{\mathrm{a}, \mathrm{b}}$, \\ Claude Estournès ${ }^{\mathrm{c}}$, Luc Brohan ${ }^{\mathrm{a}}$ \\ a Institut des Matériaux Jean Rouxel, Université de Nantes, CNRS, 2 rue de la Houssinière, BP 32229, 44322 Nantes Cedex, France \\ ${ }^{\mathrm{b}}$ Institut des Nanotechnologies de Lyon INL-UMR5270, CNRS, INSA de Lyon, Villeurbanne F-69621, France \\ ${ }^{\mathrm{c}}$ CIRIMAT, UMR 5085 CNRS - UPS-INP, 118 route de Narbonne, 31062 Toulouse Cedex, France
}

\begin{abstract}
Thin-films of $\mathrm{La}_{2} \mathrm{Ti}_{2} \mathrm{O}_{7}$ were obtained by dip-coating process using a precursor salt in nitric acid solution. The effects of solution concentration, withdrawal speed, post-annealing duration and temperature were investigated both on grain size and orientation of the $\mathrm{La}_{2} \mathrm{Ti}_{2} \mathrm{O}_{7}$ thin layers. In addition, a target with the required stoichiometry for PVD deposition of La-substituted $\mathrm{Bi}_{4} \mathrm{Ti}_{3} \mathrm{O}_{12}$ (BLT) was successfully sintered by spark plasma sintering (SPS) at $750{ }^{\circ} \mathrm{C}$. Finally ( $\left.\begin{array}{llll}0 & 1 & 1\end{array}\right)$-oriented BLT ferroelectric films have been grown by $\mathrm{RF}$ sputtering on ( 110$)$-oriented $\mathrm{La}_{2} \mathrm{Ti}_{2} \mathrm{O}_{7}$ polycrystalline thin-film. A preferential orientation of BLT thin films has been obtained after annealing at a temperature lower than $650{ }^{\circ} \mathrm{C}$.
\end{abstract}

Keywords: A. Films; A. Grain growth; A. Sintering; B. Surfaces; D. Perovskites

\section{Introduction}

Among the ferroelectric materials, perovskite type structure and layered derivatives are of great interest due to their particular characteristics: high remnant polarisation, high coercivity, low applied voltage during reading-writing cycles. First, $\mathrm{PbZr}_{x} \mathrm{Ti}_{1-x} \mathrm{O}_{3}$ (PZT) has received a great attention but is known to present a fatigue phenomenon during cycling, especially with Pt electrodes. To overcome this drawback, other perovskites derivatives, exhibiting a layered structure, were then investigated as alternative candidates. Among them, the Aurivillius's phases, $\mathrm{SrBi}_{2}(\mathrm{Nb} \text { or Ta })_{2} \mathrm{O}_{9}\left(\mathrm{SBN}\right.$ or $\mathrm{SBT}$ ) or $\mathrm{Bi}_{4-x} \mathrm{La}_{x} \mathrm{Ti}_{3} \mathrm{O}_{12}$ (BLT $x$ ), have driven a great interest due to their properties, well adapted to a potential application in non-volatile ferroelectric memories (NVFRAM). These materials are built up of $\mathrm{MO}_{6}$ octahedra sharing corners as in perovskites but, contrary to the latter only 2 (SBT and SBN) or 3 octahedra are connected in the stacking direction. The so-obtained perovskite sheets are separated by $\mathrm{Bi}_{2} \mathrm{O}_{2}{ }^{2+}$ layers adopting the fluorite

Corresponding author. Tel.: +33240 3739 96; fax: +33 240373995 . E-mail address: mireille.richard@cnrs-imn.fr (M. Richard-Plouet). arrangement. Among the $\mathrm{Bi}_{4-x} \mathrm{La}_{x} \mathrm{Ti}_{3} \mathrm{O}_{12}$ solid solution, the composition $x=0.75$, exhibits a high resistance to fatigue during cycling. ${ }^{1}$ To explain such behaviour, different models have been proposed. ${ }^{2,3}$ The great potential of BLT relies on the anisotropic polarisation which lies along $\left[\begin{array}{lll}1 & 0 & 0\end{array}\right]^{4-7}$ Thus an enhancement of BLT ferroelectric response could be achieved by deposition in thin layers with the [1 000$]$ axis aligned perpendicularly to the bottom electrode and to the substrate. In literature such a preferential orientation has been obtained by titanate deposition on a (1 10$)$ oriented conductive $\mathrm{SrRuO}_{3}$ perovskite electrode ${ }^{8,9}$ or on $\left(\begin{array}{lll}1 & 1 & 0\end{array}\right)$ Pt faces thanks to the low misfit with the $\left(\begin{array}{lll}1 & 1 & 0\end{array}\right)$ planes of perovskite. ${ }^{10} \mathrm{~A}$ second family of layered perovskites also exhibits a great potential: Nanot-Queyroux' phases $\mathrm{A}_{n} \mathrm{~B}_{n} \mathrm{X}_{3 n+2}$, $2 \leq n \leq 6, \mathrm{~A}=\mathrm{Ln}, \mathrm{Sr}, \mathrm{Ba}, \mathrm{Na}, \mathrm{B}=\mathrm{Ti}, \mathrm{Nb}, \mathrm{Ta}, \mathrm{X}=\mathrm{O}, \mathrm{F}$ which are constituted of stacked layers which are cut off along the (1 110$)$ plane of the perovskite instead of the $\left(\begin{array}{ll}1 & 0\end{array}\right)$ one in SBT or BLT. Indeed, [ $\left[\begin{array}{lll}0 & 0 & 1\end{array}\right]$ oriented films exhibit a (1 110$)$ plane at the upper surface well suitable as a buffer layer to induce the orientation of BLT along [ $\left.\begin{array}{llll}1 & 0 & 0\end{array}\right]$. In order to minimise the misfit between both titanates, $\mathrm{La}_{2} \mathrm{Ti}_{2} \mathrm{O}_{7}{ }^{11,12}(n=4$, denoted LTO $)$ was chosen as a buffer layer. LTO exhibits a high Curie temperature of $1500^{\circ} \mathrm{C}$, piezoelectric and electro-optic effects ${ }^{13,14}$. Since $\mathrm{La}_{2} \mathrm{Ti}_{2} \mathrm{O}_{7}$ melt congruently at $1790{ }^{\circ} \mathrm{C},{ }^{15}$ obtaining a pure phase generally 


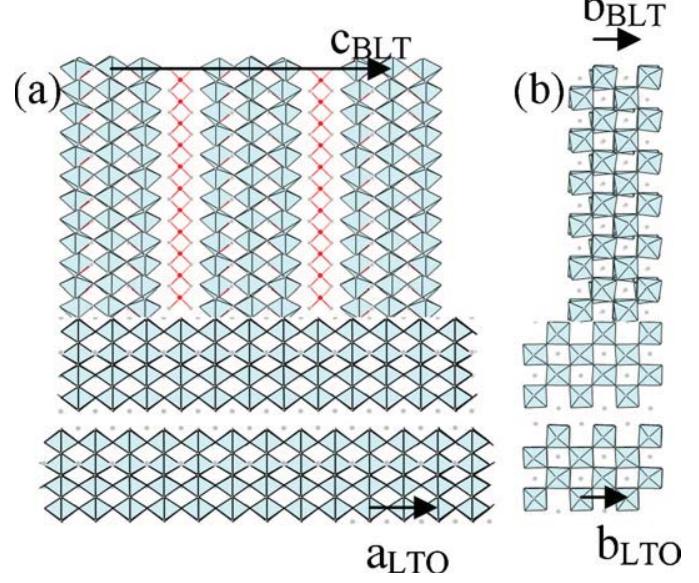

Fig. 1. Representations of the epitaxy relationship between LTO and BLT along: (a) $b_{\mathrm{LTO}}$ and $b_{\mathrm{BLT}}$ and (b) $a_{\mathrm{LTO}}$ and $c_{\mathrm{BLT}}$.

require annealing at high temperatures, especially when using a classical solid-state reaction involving lanthanum and titanium oxides. Recently, a flux method was reported to allow the formation of $\mathrm{La}_{2} \mathrm{Ti}_{2} \mathrm{O}_{7}$ at $1100{ }^{\circ} \mathrm{C} .{ }^{16}$ Alternative low temperature routes were also developed involving co-precipitation ${ }^{17,18}$ or urea precipitation, ${ }^{19}$ hydrothermal treatments, ${ }^{20-22}$ polymerisable complex methods, ${ }^{23-28}$ and more largely sol-gel techniques. ${ }^{29-31}$ The most usual reactant for Titanium oxide is then an alkoxide $\left(\mathrm{Ti}_{(}\left(\mathrm{OC}_{3} \mathrm{H}_{7}\right)_{4}\right.$ or $\left.\mathrm{Ti}\left(\mathrm{OC}_{4} \mathrm{H}_{9}\right)_{4}\right)$ and 2methoxyethanol is generally used as solvent, especially for thin film obtained by chemical solution deposition. ${ }^{32-36}$ Pulsed laser deposition was also used but requires a severe control of air atmosphere to avoid $\mathrm{Ti}^{4+}$ reduction. ${ }^{37-40}$

Recently, researchers suggested that the use of a buffer layer might be an interesting solution to obtain bilayered perovskite films with enhanced dielectric constant. ${ }^{41-43}$ Therefore, on the basis of previous results on BLT thin films deposition by RF magnetron sputtering, ${ }^{44}$ we present here first investigations on the effect of a $\mathrm{La}_{2} \mathrm{Ti}_{2} \mathrm{O}_{7}$ buffer layer, previously deposited by dip coating, on both, structure and orientation of the BLT films deposited subsequently by RF magnetron sputtering.

The challenge is thus to develop in the LTO layer a grain growth with the $c$-axis perpendicular to the substrate and to further induce the BLT deposition along $a$-axis, as illustrated in Fig. 1. The structural arrangement of $\mathrm{La}_{2} \mathrm{Ti}_{2} \mathrm{O}_{7}$ is described in a monoclinic cell with $a_{\mathrm{LTO}}=7.812(2), b_{\mathrm{LTO}}=5.5440(7)$ and $c_{\mathrm{LTO}}=13.010(2), \beta=98.66(1)^{\circ} .{ }^{12}$ The lattice parameters of $\mathrm{Bi}_{3.25} \mathrm{La}_{0.75} \mathrm{Ti}_{3} \mathrm{O}_{12}$ are $a_{\mathrm{BLT}}=5.4181(6), b_{\mathrm{BLT}}=5.4168(3)$ and $c_{\mathrm{BLT}}=32.8856(4) .{ }^{45}$ Along [ $\left[\begin{array}{ll}0 & 1\end{array}\right]$ LTO or BLT (Fig. 1a), the mismatch between $c_{\text {BLT }}$ and $4 \times$ a aTO is less than $5 \%$, in the other direction (Fig. 1b) the mismatch is $0.4 \%$. In this ideal configuration, BLT would be in compression along $c_{\mathrm{BLT}}$ and in tension along $b_{\mathrm{BLT}}$.

We report here a method allowing the preparation of $\mathrm{La}_{2} \mathrm{Ti}_{2} \mathrm{O}_{7}$ as films, starting from inorganic reactants. Instead of the usual reactants for Ti precursors such as titanium isopropoxide or titanium acetylacetonate, a Ti oxychoride solution is used. Films are heated in air after dip coating in an acid solution containing the stoichiometric reactant salts. Second, among deposition techniques, sputtering or physical vapour deposition technique (PVD) enables to deposit at low temperature wellcrystallised films with a good uniformity over large areas. An optimisation of the deposition conditions allowed us to induce a preferential orientation of the BLT film.

\section{Experimental}

\subsection{Synthesis}

The solution containing $\mathrm{La}$ and $\mathrm{Ti}$ was freshly prepared in decarbonated water $(18.2 \mathrm{M} \Omega$, in resistivity). In order to avoid Ti alkoxide or complexing chelate, such as acetylacetonate, we developed a method using only inorganic reactants for Ti, starting from $\mathrm{TiOCl}_{2}$ solution (Millenium $\mathrm{TiOCl}_{2} \cdot 1.4 \mathrm{HCl} \cdot 7 \mathrm{H}_{2} \mathrm{O}$, $5 \mathrm{~mol} \mathrm{~L}^{-1}$ in $\mathrm{HCl}$ ). First, a $\mathrm{TiO}_{2} \cdot n \mathrm{H}_{2} \mathrm{O}$ gel was precipitated by ammonia (typically $1 \mathrm{~mL} \mathrm{TiOCl} 2$ is precipitated with $10 \mathrm{~mL}$ $\mathrm{NH}_{4} \mathrm{OH}, 6.5 \mathrm{~mol} \mathrm{~L}^{-1}$ ). Before mixing with the lanthanum nitrate solution, $\mathrm{Cl}^{-}$ions were removed by filtering and carefully washing with de-ionized-water. Second, the solid was dissolved in nitric acid $\left(5 \mathrm{~mL} \mathrm{HNO}_{3}, 5 \mathrm{~mol} \mathrm{~L}^{-1}\right)$. In such conditions, a stable solution with a $\left[\mathrm{Ti}^{4+}\right]$ concentration up to $1 \mathrm{~mol} \mathrm{~L}^{-1}$ can be prepared. Third, the required amount of lanthanum nitrate was added to this solution in order to adjust the required $\mathrm{La}^{3+}$ and $\mathrm{Ti}^{4+}$ concentration in the studied range, i.e. $0.15-0.90 \mathrm{~mol} \mathrm{~L}^{-1}$.

$\mathrm{Si}\left(\begin{array}{lll}1 & 0 & 0\end{array}\right)$ wafers, pre-treated with $\mathrm{HCl}$ and then boiling acetone or ethanol were used as substrates. Dip coatings were performed with a DC-multi/4 Nima Dip Coater. The substrate was maintained in the solution for $2 \mathrm{~min}$ and then pulled out at different rates: 15, 40, 80 and $120 \mathrm{~mm} \mathrm{~min}^{-1}$. Then, each layer was allowed to dry for $1 \mathrm{~h}$ at room temperature in a $50 \%$ RH atmosphere. Six deposition-drying cycles were performed before any annealing at high temperature. Then, the films were annealed at temperature in the $600-1200^{\circ} \mathrm{C}$ domain for a duration ranging from 4 to $12 \mathrm{~h}$ under air atmosphere.

The target, with required stoichiometry and density, suitable for RF sputtering experiments, was prepared by spark plasma sintering (SPS). The BLT powder was obtained by precipitation with ammonium hydroxide of a solution in nitric acid. The required amount of $\mathrm{Bi}\left(\mathrm{NO}_{3}\right)_{3} \cdot 5 \mathrm{H}_{2} \mathrm{O}$ and $\mathrm{La}\left(\mathrm{NO}_{3}\right)_{3} \cdot 6 \mathrm{H}_{2} \mathrm{O}$ dissolved in concentrated nitric acid were added to a $\left[\mathrm{Ti}^{4+}\right]$ $\left(0.5 \mathrm{~mol} \mathrm{~L}^{-1}\right)$ solution obtained as described above. After precipitation with ammonium hydroxide, a thermal treatment at $600{ }^{\circ} \mathrm{C}$ was performed for hydroxide decomposition before sintering. The powder has been sintered using SPS apparatus (Model Dr Sinter SPS-2080 SPS Syntex INC Japan). The SPS equipment consists of a pulsed (3.3 ms of duration) direct current generator, an hydraulic press system, a vacuum and water cooled chamber, upper and lower punch electrodes graphite spacers, punches and sintering die and finally control systems for the temperature (thermocouple or optical pyrometer), environment pressure inside the chamber and for the positioning of the lower electrode on $z$-axis which allows us to follow the shrinkage of the sample. The pulse sequence used is 12-2 (pulses-dead time or zero current) as recommended by the SPS equipment constructor. The temperature was monitored and regulated using a thermocouple fixed in a little hole situated at the surface of 
the die. The temperature was raised from room temperature to $750{ }^{\circ} \mathrm{C}$ with a heating rate of $25^{\circ} \mathrm{C} / \mathrm{min}$. A $50 \mathrm{MPa}$ uniaxial pressure was applied while increasing temperature from 650 to $750{ }^{\circ} \mathrm{C}$. In these conditions, during the sintering cycle, the voltage reached a maximum value of $2.2 \mathrm{~V}$ and the maximum value of current passing through the die reached the applied value of $1480 \mathrm{~A}$. This process led to a pellet, with the following dimensions: $0.3 \mathrm{~cm}$ thick and $3 \mathrm{~cm}$ diameter, and density very close to the theoretical one, i.e. equal to $97 \%$ and thus, suitable as a target for magnetron sputtering deposition.

The BLT films were deposited by RF magnetron sputtering in a customized reactor equipped with a $25 \mathrm{~mm}$ diameter planar magnetron cathode as described previously. ${ }^{44}$ Depositions were performed at $60 \mathrm{~W}$ RF power and a total pressure of 47 mTorr, in an argon/oxygen gas mixture containing $10 \% \mathrm{O}_{2}$. Substrates were located downstream at $7.5 \mathrm{~cm}$ from the target. Depositions were performed for 70 min either in a one step or two-step deposition process. ${ }^{46,47}$ All BLT depositions were performed without heating the substrate. A $1 \mathrm{~h}$ ex situ annealing under flowing oxygen at $650^{\circ} \mathrm{C}$ allows obtaining well-crystallised BLT films. For a two-step deposition process, one intermediate and one final ex situ annealing were performed at $650{ }^{\circ} \mathrm{C}$ under flowing oxygen during $1 \mathrm{~h}$. The effect of a $3 \mathrm{~h}$ ex situ final annealing was also investigated.

\subsection{Characterisation}

Thermal gravimetric analysis (TGA) was performed in argon atmosphere with a TG-92 Setaram equipment at temperature ranging from room temperature to $1200^{\circ} \mathrm{C}$ and a heating rate of $10^{\circ} \mathrm{C} \mathrm{min}^{-1}$. A mass spectrometer connected to the TG apparatus allows the identification of the released products during heating.

AFM imaging was performed before thermal treatment using a Nanoscope Ш externder Ex-1, digital instruments Inc in tapping mode.

The X-ray diffraction (XRD) patterns were recorded at a $1^{\circ}$ grazing angle in the $5-55^{\circ}, 2 \theta$ domain, with a $0.03^{\circ}$ step scan. To enhance the signal to noise ratio, each pattern was accumulated for $3 \mathrm{~h}$. The preferential orientation of the films was estimated from X-ray diffraction intensities using the Lotgering orientation factor $f=\left(p-p_{\mathrm{o}}\right) /\left(1-p_{\mathrm{o}}\right)$, where $p=\Sigma \mathrm{I}_{(00 l)} / \Sigma \mathrm{I}_{(h k l)}$ and $\mathrm{p}_{\mathrm{o}}$ is the $\mathrm{p}$ value for a random powder pattern. ${ }^{48} \mathrm{In}$ case of a diffraction peak including several $(h k l)$ reflections, a decomposition of the peak using pseudo-Voigt profiles has been performed to correctly estimate the reflection intensities. As an example, the peak at $27.8^{\circ}$ was decomposed in two components associated to the $\left(\begin{array}{lll}0 & 0 & 4)\end{array}\right)$ and $(-211 / 210)$ reflections.

Scanning electron microscopy (SEM) images were carried out with a JEOL JSM-6400F microscope (Akishima, Japan) equipped with a field emission gun, operating at $7 \mathrm{kV}$. Bulk chemical composition of the films was determined by energy dispersive spectrometry (EDS) at $15 \mathrm{kV}$ with a JEOL JSM-5800.

TEM observations of cross-sections were performed with a Hitachi HF2000 FEG operating at $200 \mathrm{kV}$, after samples preparation by mechanical polishing using tripod technique.

\section{Results and discussion}

\subsection{Characterisation of the solid precursor for $\mathrm{La}_{2} \mathrm{Ti}_{2} \mathrm{O}_{7}$}

The first step of this study was to characterise the required temperature for $\mathrm{La}_{2} \mathrm{Ti}_{2} \mathrm{O}_{7}$ phase formation in thin films. Therefore, water was evaporated from the reactant solution by drying in a closed container containing $\mathrm{P}_{2} \mathrm{O}_{5}$, for 5 days. TGA curve of the obtained solid (Fig. 2) shows four decomposition steps and a weight loss achieved at $600{ }^{\circ} \mathrm{C}$. According to Gobichon et al. works, ${ }^{49}$ the thermal decomposition of lanthanum nitrate hexahydrate can be usually divided in three steps: first, dehydration below $200{ }^{\circ} \mathrm{C}$, second formation of $\mathrm{LaONO}_{3}$ between 240 and $380^{\circ} \mathrm{C}$ with elimination of two nitrate groups and finally formation of $\mathrm{La}_{2} \mathrm{O}_{3}$ with nitrate loss between 400 and $520^{\circ} \mathrm{C}$. Thus, in our case, the first step, between room temperature and $240{ }^{\circ} \mathrm{C}$, is associated to a water departure, corresponding to the partial dehydration of $\mathrm{TiO}_{2} \cdot n \mathrm{H}_{2} \mathrm{O}$ and $\mathrm{La}\left(\mathrm{NO}_{3}\right) \cdot 6 \mathrm{H}_{2} \mathrm{O}$. The second one, occurring between 240 and $360{ }^{\circ} \mathrm{C}$, corresponds to a further release of water and nitrates (as $\mathrm{NO}, \mathrm{O}_{2}$ and $\mathrm{N}_{2} \mathrm{O}$ and $\mathrm{N}_{2}$ ), and is mainly related to the beginning of $\mathrm{LaONO}_{3}$ formation and the further degradation of $\mathrm{TiO}_{2} \cdot n \mathrm{H}_{2} \mathrm{O}$. The two last weight losses, occurring, respectively in the $360-460^{\circ} \mathrm{C}$ and $460-600^{\circ} \mathrm{C}$ ranges can be attributed to the decomposition of $\mathrm{La}\left(\mathrm{NO}_{3}\right)_{3}$.

As a second step, the anhydrous solid is heated at temperatures above $600{ }^{\circ} \mathrm{C}$ for $4 \mathrm{~h}$ and then the evolution of the $\mathrm{X}$-ray diffraction patterns with temperature has been followed. At $600^{\circ} \mathrm{C}$, a broad hump appears around $2 \theta=30^{\circ}$ indicating that the solid is not ordered over a long range. At $800^{\circ} \mathrm{C}$, only part of the sample crystallised in the expected $\mathrm{La}_{2} \mathrm{Ti}_{2} \mathrm{O}_{7}$ phase whereas the high level of the background in the XRD pattern gives evidence for an amorphous content. The synthesis of $\mathrm{La}_{2} \mathrm{Ti}_{2} \mathrm{O}_{7}$ at

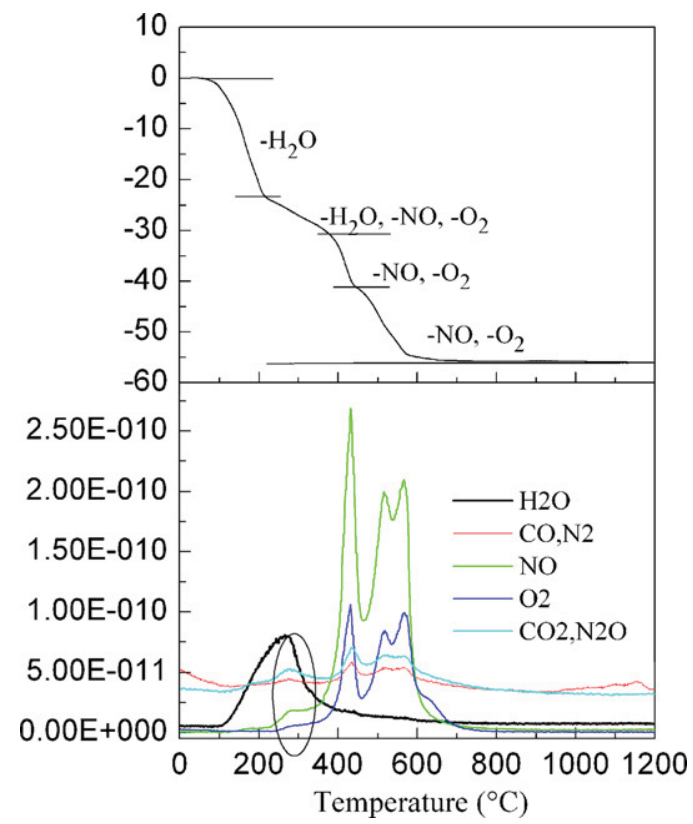

Fig. 2. TGA and mass spectrum performed on the solid obtained after evaporation of water from the $\mathrm{HNO}_{3}$ solution containing the reactant, $\left[\mathrm{Ti}^{4+}\right]=\left[\mathrm{La}^{3+}\right]=0.30 \mathrm{~mol} \mathrm{~L}^{-1}$. 


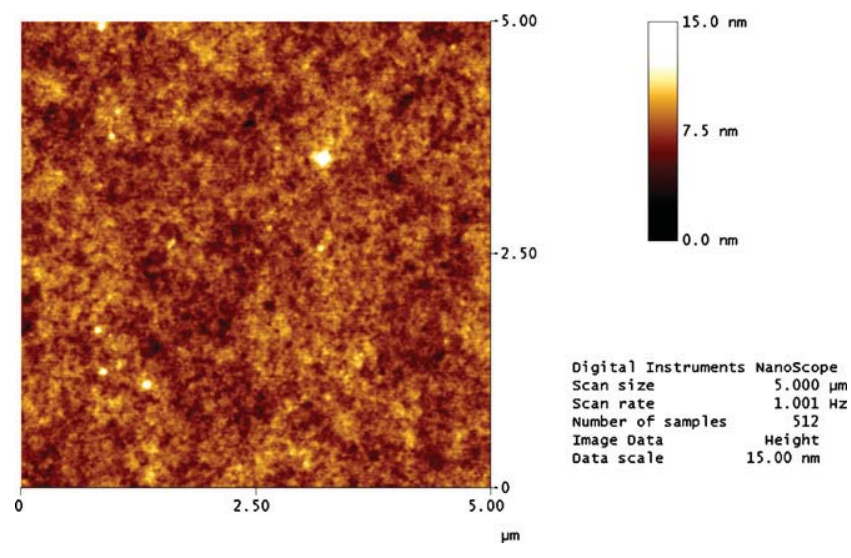

Fig. 3. AFM image of a film obtained by dip coating in a $\left[\mathrm{Ti}^{4+}\right]=0.30 \mathrm{~mol} \mathrm{~L}^{-1}$ solution, withdrawal speed of $40 \mathrm{~mm} \mathrm{~min}^{-1}$, dried at RT after each 6 dips.

such low temperature shows that this method leads to a homogenous chemical composition at a very small scale. As reported by Suresh et al., ${ }^{19}$ a temperature higher than $1000^{\circ} \mathrm{C}$ is required to crystallise lanthanum titanate and eliminate any trace of amorphous phase. This preliminary study allowed us to check that our procedure leads undeniably to the crystallisation of $\mathrm{La}_{2} \mathrm{Ti}_{2} \mathrm{O}_{7}$.

\subsection{Chemical solution deposition of $\mathrm{La}_{2} \mathrm{Ti}_{2} \mathrm{O}_{7}$}

The next objective was to develop in the films a grain growth with the $c$-axis perpendicular to the substrate. The LTO thin films were obtained at RT by six dip-coating cycles in a $\left[\mathrm{Ti}^{4+}\right]=0.30 \mathrm{~mol} \mathrm{~L}^{-1}$ solution, followed by a drying step at RT before any thermal treatment. Fig. 3 shows the AFM image of the surface of the film. A granular morphology is observed exhibiting a homogenous distribution in size in the $30 \mathrm{~nm}$ range. The roughness determined on a $5 \mu \mathrm{m} \times 5 \mu \mathrm{m}$ surface is $1 \mathrm{~nm}$. Finally, as checked by EDX analysis, the La/Ti ratio is equal to 1 , as expected.

In Fig. 4, the XRD diffraction patterns of LTO films are presented for different annealing conditions. As already mentioned in the previous section concerning the anhydrous powder-like solid, annealing at $600^{\circ} \mathrm{C}$, for $12 \mathrm{~h}$ does not permit the crystallisation of $\mathrm{La}_{2} \mathrm{Ti}_{2} \mathrm{O}_{7}$ (Fig. 4a). Second, the high level of the background in the X-ray diffraction pattern obtained for a film heated for $12 \mathrm{~h}$, at $800{ }^{\circ} \mathrm{C}$, indicates that again only a part of the solid has crystallised (Fig. 4b). After annealing at $1000^{\circ} \mathrm{C}$ (Fig. 4c), the quality of the pattern is slightly enhanced with the appearance typical reflections attributable to $\mathrm{La}_{2} \mathrm{Ti}_{2} \mathrm{O}_{7}$. However, the signal still remains noisy. Increasing the withdrawal speed to $80 \mathrm{~mm} \mathrm{~min}^{-1}$, significantly improves the pattern quality, even after a shorter thermal treatment of $4 \mathrm{~h}$ at $1000^{\circ} \mathrm{C}$ (Fig. 4d). This observation confirms that withdrawal speed is a major parameter in dip-coating technique. Indeed the layer thickness, $h$, depends on the solution adhesion to the substrate, which is governed through the following Landau-Levich equation: ${ }^{50}$

$h=0.94 \times\left(\frac{\mu v}{\sigma}\right)^{2 / 3}\left(\frac{\sigma}{\rho g}\right)^{1 / 2}$

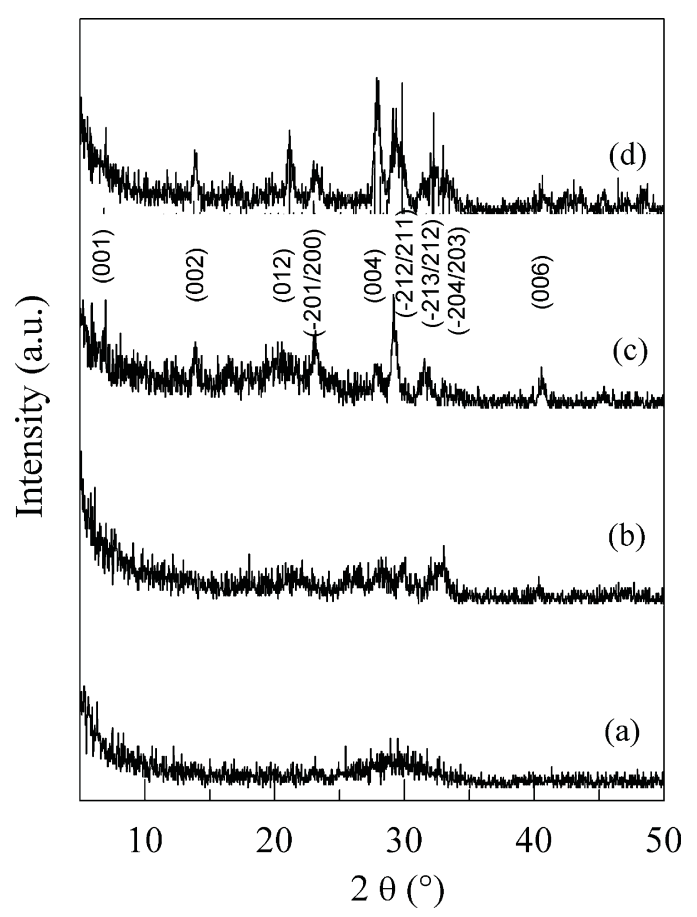

Fig. 4. X-ray diffraction of films dried at RT after 6 dips in a $\left[\mathrm{Ti}^{4+}\right]=0.30 \mathrm{~mol} \mathrm{~L}^{-1}$ solution, withdrawal speed of $40 \mathrm{~mm} \mathrm{~min}^{-1}$, annealed for $12 \mathrm{~h}$ at (a) $600{ }^{\circ} \mathrm{C}$, (b) $800^{\circ} \mathrm{C}$, (c) $1000^{\circ} \mathrm{C}$, withdrawal speed of $80 \mathrm{~mm} \mathrm{~min}^{-1}$, annealed at $1000^{\circ} \mathrm{C}$ for (d) $4 \mathrm{~h}$ bars: diffraction peaks of $\mathrm{La}_{2} \mathrm{Ti}_{2} \mathrm{O}_{7}$, JCPDS file no. 81-1066.

where $v$ is the withdrawal speed, $\mu$ the viscosity of the solution, $\sigma$ the liquid-vapour surface tension and $\rho$ is the density of the solution. This first study indicates that annealing at $1000{ }^{\circ} \mathrm{C}$ is required to crystallise $\mathrm{La}_{2} \mathrm{Ti}_{2} \mathrm{O}_{7}$ and that increasing the withdrawal speed by increasing the amount of available precursor favours its crystallisation.

Several speeds were thus tested leading to the adhesion of different amount of liquid. Since the SEM images performed with secondary electrons were not contrasted enough for the thinner layers, the thickness was estimated using the backscattered electron mode (Fig. 5). In this mode, the contrast associated with the heavy La atoms is bright then the darker contrast is associated to the $\mathrm{SiO}_{2}$ layer on top of the $\mathrm{Si}$ wafer. SEM images reveal that the thickness of the film is around $50 \mathrm{~nm}$ for 15 and $40 \mathrm{~mm} \mathrm{~min}^{-1}$ (Fig. 5a and c), reaches $75 \mathrm{~nm}$ when dipping at $80 \mathrm{~mm} \mathrm{~min}^{-1}$ (Fig. 5e) and less than $20 \mathrm{~nm}$ for $120 \mathrm{~mm} \mathrm{~min}^{-1}$ (Fig. $5 \mathrm{~g}$ ). The accuracy of the measurement is not higher than $20 \mathrm{~nm}$. For a $200 \mathrm{~mm} \mathrm{~min}^{-1}$ dipping rate, the film is $400 \mathrm{~nm}$ thick as revealed by the SEM cross-view in secondary electron mode (Fig. 5i). SEM images at low magnification allow us to estimate the substrate coverage. As revealed by Fig. 5j, the homogeneity is clearly better for a dipping rate equal to $200 \mathrm{~mm} \mathrm{~min}^{-1}$ (bottom row of images). The particles size also depends on the withdrawal speed. For all the studied conditions, the grain size distribution is bimodal: a first population of particles exhibits grain size ranging from 50 to $100 \mathrm{~nm}$ and a second one with grain size in $100-270 \mathrm{~nm}$ as observed in Fig. 5. For a dip performed at $15 \mathrm{~mm} \mathrm{~min}^{-1}$, the grain size of both populations is centred on 80 and $130 \mathrm{~nm}$ 

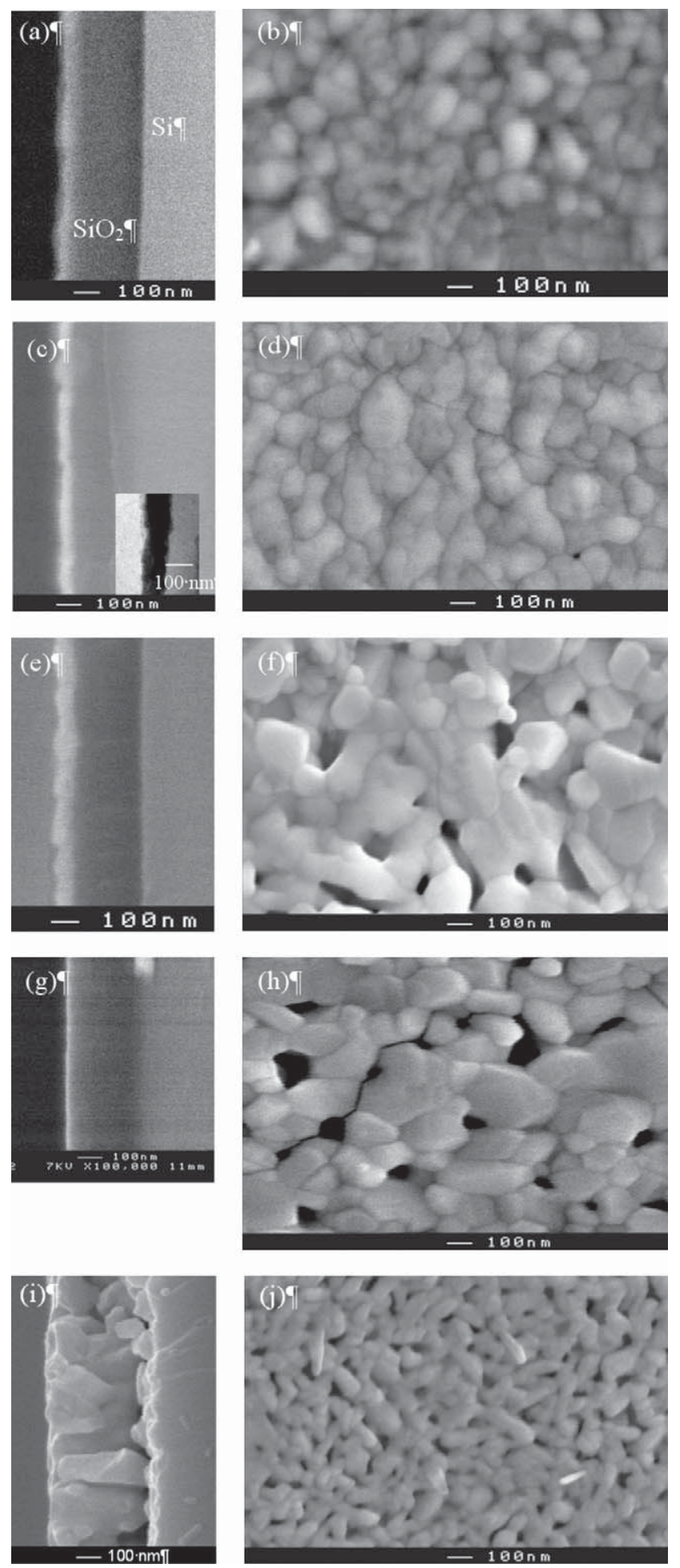

Fig. 5. SEM images of $\mathrm{La}_{2} \mathrm{Ti}_{2} \mathrm{O}_{7}$ films obtained by dip coating in a $\left[\mathrm{Ti}^{4+}\right]=0.30 \mathrm{~mol} \mathrm{~L}^{-1}$ solution then annealed at $1000^{\circ} \mathrm{C}$ for $12 \mathrm{~h}$ in air, at various withdrawal speeds $15 \mathrm{~mm} \mathrm{~min}^{-1}$ (a) backscattered imaging of a cross-view, (b) high magnification, $40 \mathrm{~mm} \mathrm{~min}^{-1}$, (c) backscattered imaging of a cross-view, inset: TEM cross-view, (d) high magnification, $80 \mathrm{~mm} \mathrm{~min}^{-1}$, (e) backscattered imaging of a cross-view, low and (f) high magnification, $120 \mathrm{~mm} \mathrm{~min}^{-1}$, (g) backscattered imaging of a cross-view, (h) high magnification secondary images and $200 \mathrm{~mm} \mathrm{~min}^{-1}$, (i) backscattered imaging of a cross-view, and (j) high magnification secondary images.

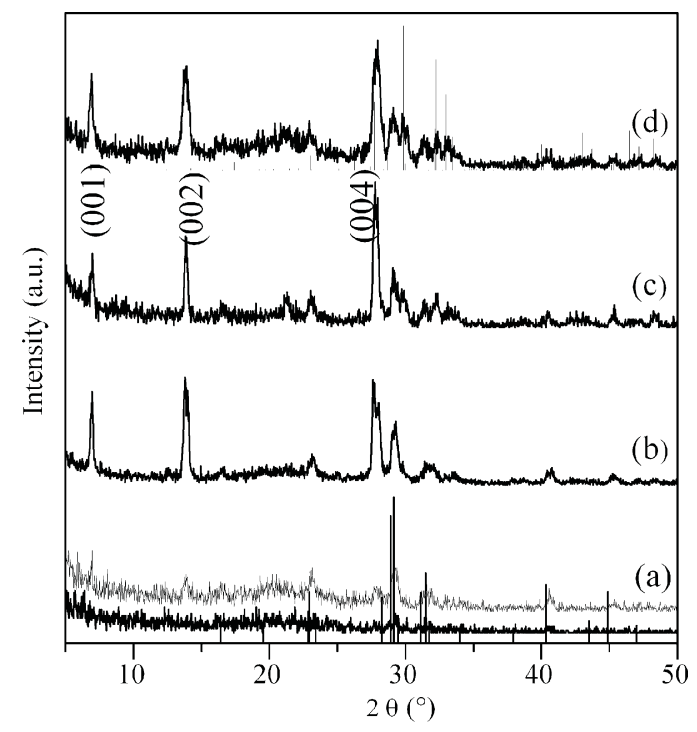

Fig. 6. X-ray diffraction patterns of various films, prepared at different withdrawal speeds: (a) $15 \mathrm{~mm} \mathrm{~min}^{-1}$ (lower line) and $40 \mathrm{~mm} \mathrm{~min}^{-1}$ (upper line), bars: diffraction peaks of $\mathrm{La}_{2} \mathrm{Ti}_{2} \mathrm{SiO}_{9}$, JCPDS file no. 82-1490, (b) $80 \mathrm{~mm} \mathrm{~min}^{-1}$, (c) $120 \mathrm{~mm} \mathrm{~min}^{-1}$, and (d) $200 \mathrm{~mm} \mathrm{~min}^{-1}$, annealed at $1000^{\circ} \mathrm{C}$ for $12 \mathrm{~h}$, bars: diffraction peaks of $\mathrm{La}_{2} \mathrm{Ti}_{2} \mathrm{O}_{7}$, JCPDS file no. 81-1066.

(Fig. 5b). The first population exhibits a grain size in the $100 \mathrm{~nm}$ range for the intermediate rates. The grain size of bigger particles increases up to $200-220 \mathrm{~nm}$ and even up to $270 \mathrm{~nm}$ for $120 \mathrm{~mm} \mathrm{~min}^{-1}$ (Fig. 5d, f and h). For a $200 \mathrm{~mm} \mathrm{~min}^{-1}$ dipping rate, the grain size of both populations is centred on 50 and $100 \mathrm{~nm}$ (Fig. 5j).

Fig. 6 shows the evolution of the XRD patterns for thin layers obtained with a $\left[\mathrm{Ti}^{4+}\right]=0.30 \mathrm{~mol} \mathrm{~L}^{-1}$ solution at different rates and after a further annealing of $12 \mathrm{~h}$ at $1000^{\circ} \mathrm{C}$. Crystallisation of the titanate and its orientation along [ 001 ] could be achieved for dipping rates equal or above $80 \mathrm{~mm} \mathrm{~min}^{-1}$ (Fig. 6b-d). For lower withdrawal speeds, the diffraction peaks are almost hidden in the background of the pattern, especially for the lowest rate $15 \mathrm{~mm} \mathrm{~min}^{-1}$ (Fig. 6a). Moreover, for $40 \mathrm{~mm} \mathrm{~min}^{-1}$ (Fig. 6b) even if the $(00 l)$ peaks of $\mathrm{La}_{2} \mathrm{Ti}_{2} \mathrm{O}_{7}$ are detected, the most detectable peaks are attributed to a lanthanum titanium silicate $\left(\mathrm{La}_{2} \mathrm{Ti}_{2} \mathrm{SiO}_{9}\right.$, JCPDS file No. 82-1490, marked by black bars in Fig. 6a). We assume that $\mathrm{Si}$ atoms may diffuse from the substrate at $1000^{\circ} \mathrm{C}$, leading to the crystallisation of this titano-silicate, usually obtained at $850-9500^{\circ} \mathrm{C}$ temperature range.$^{51}$ In addition, as can be seen in Fig. $4 \mathrm{~d}$ decreasing the temperature and duration of the thermal treatment do not prevent this crystallisation. This silicate seems to be formed to the detriment of $\mathrm{La}_{2} \mathrm{Ti}_{2} \mathrm{O}_{7}$ when there is not enough amount of reactant on the substrate. To verify this hypothesis, depositions were performed with a $\left[\mathrm{Ti}^{4+}\right]=0.15 \mathrm{~mol} \mathrm{~L}^{-1}$ solution: they lead to the only formation of the silicate. Unfortunately, this impurity cannot be avoided in the films obtained at rates of 80 and $120 \mathrm{~mm} \mathrm{~min}^{-1}$. Nevertheless they mainly exhibit the diffraction peaks of $\mathrm{La}_{2} \mathrm{Ti}_{2} \mathrm{O}_{7}$ and in particular a preferential orientation could be induced along [ $\left[\begin{array}{lll}0 & 1\end{array}\right]$ since the intensity of $(00 l)$ reflections is enhanced when compared to the expected intensities (black lines in Fig. 6d). 


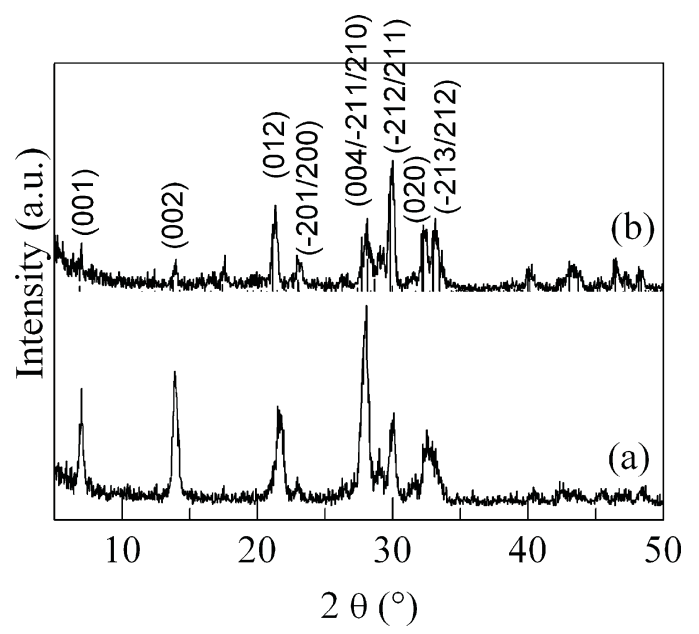

Fig. 7. X-ray diffraction patterns of films, dried at RT after 6 dips in a $\left[\mathrm{Ti}^{4+}\right]=0.90 \mathrm{~mol} \mathrm{~L}^{-1}$ solution prepared at different withdrawal speeds: (a) $40 \mathrm{~mm} \mathrm{~min}^{-1}$, (b) $80 \mathrm{~mm} \mathrm{~min}^{-1}$, annealed at $1000^{\circ} \mathrm{C}$ for $12 \mathrm{~h}$ (black bars: diffraction peaks of $\mathrm{La}_{2} \mathrm{Ti}_{2} \mathrm{O}_{7}$, JCPDS file no. 81-1066).

To favour the formation of the titanate to the detriment of the silicate, further attempts with higher concentrated solution were undertaken, namely $\left[\mathrm{Ti}^{4+}\right]=0.90 \mathrm{~mol} \mathrm{~L}^{-1}$. The AFM image of a film surface, obtained before annealing with such a solution at $80 \mathrm{~mm} \mathrm{~min}^{-1}$ is very similar to Fig. 3, i.e. the one obtained for a film with $\left[\mathrm{Ti}^{4+}\right]=0.30 \mathrm{~mol} \mathrm{~L}^{-1}$. The roughness is again lower than $1.5 \mathrm{~nm}$. In both experimental conditions, the evaporation of the solvent at RT in a controlled humidity induces the formation of colloids which are $30 \mathrm{~nm}$ in diameter at the surface of the substrate. Therefore we conclude that the nucleation is most probably homogenous in the liquid phase. Contrary to the lower concentrated solution, the $\left[\mathrm{Ti}^{4+}\right]=0.90 \mathrm{~mol} \mathrm{~L}^{-1}$ solution avoids the formation of the silicate, as checked by XRD in Fig. 7. For a higher dipping rate of $80 \mathrm{~mm} \mathrm{~min}^{-1}$, a characteristic powder-like $\mathrm{La}_{2} \mathrm{Ti}_{2} \mathrm{O}_{7}$ pattern is recorded (Fig. 7b). Besides, when the deposition is performed at $40 \mathrm{~mm} \mathrm{~min}^{-1}$ rate, the intensity of the $(00 l)$ reflections is enhanced, indicating that a $\left(\begin{array}{lll}0 & 0 & 1\end{array}\right)$ orientation can be favoured. The measurement of the layer thickness obtained at $40 \mathrm{~mm} \mathrm{~min}^{-1}$ was too weak to be checked on SEM images. For a dipping rate of $80 \mathrm{~mm} \mathrm{~min}^{-1}$, a $260 \mathrm{~nm}$ thick porous film was characterised. Furthermore, for a dipping rate of $40 \mathrm{~mm} \mathrm{~min}^{-1}$, SEM image allows us to estimate the particle grain size to 110 and $280 \mathrm{~nm}$ for the smallest and greatest particles, respectively (Fig. 8a). For a faster rate of $80 \mathrm{~mm} \mathrm{~min}^{-1}$, both grain sizes decrease to $70-80 \mathrm{~nm}$ and $230 \mathrm{~nm}$, for the smallest and greatest particles, respectively (Fig. 8b).

The $f$ Lotgering factors are reported in Table 1. For a randomly oriented powder the $\mathrm{f}$ value is equal to 0 whereas for a textured sample, the f factor reaches 1 . However, this simple estimation allows us to determine that the most oriented samples, i.e. $60 \%$ oriented are obtained from a $\left[\mathrm{Ti}^{4+}\right]=0.30 \mathrm{~mol} \mathrm{~L}^{-1}$ solution with a 80 or $200 \mathrm{~mm} \mathrm{~min}^{-1}$ withdrawal speed. From the Landau-Levich equation, the corresponding amounts of $\mathrm{La}_{2} \mathrm{Ti}_{2} \mathrm{O}_{7}$ reactant available for the different experimental conditions can be calculated (Table 1, fourth column). The orientation seems to be favoured when the amount of reactant available on the surface lies between $1.6 \times 10^{-1}$ and $3.0 \times 10^{-1} \mu \mathrm{mol} \mathrm{cm}{ }^{-2}$. For the lower limit and below, the amount of reactant is not high enough to hinder the reaction of $\mathrm{SiO}_{2}$ with the precursor and the silicate crystallises. In the other case, the grain growth is then favoured and the interfacial energy between the film and the substrate is decreased. Due the layered structure of $\mathrm{La}_{2} \mathrm{Ti}_{2} \mathrm{O}_{7}$, the grain growth is expected to be faster along the directions belonging to the ( $\mathrm{a}$ and $\mathrm{b}$ ) plane and not along the stacking axis. Thus a preferential orientation is obtained along [0 0101$]$. It has to be noted, that $\mathrm{f}$ factors are only indicative and further texture measurements are required to get more precise information. As already reported, ${ }^{35}$ the degree of texture is closely linked to the amount of reactant available to form the oxide: the most diluted solution led to the highest textured film. In agreement with these results obtained by spin coating, when the concentration of the solution increases, the film is less textured due the enhancement of nucleation to the detriment of growth. Thicker films growth is less governed by the minimisation of interfacial energy and together with the nucleation enhancement, less oriented films are produced.

\subsection{RF magnetron sputtering of BLT on oriented LTO}

In the synthesis of bismuth titanates, the major difficulty is the volatility of $\mathrm{Bi}_{2} \mathrm{O}_{3}$ which melts at $830{ }^{\circ} \mathrm{C} .{ }^{52}$ To avoid this drawback, many syntheses are performed with an excess of $\mathrm{Bi}_{2} \mathrm{O}_{3}$
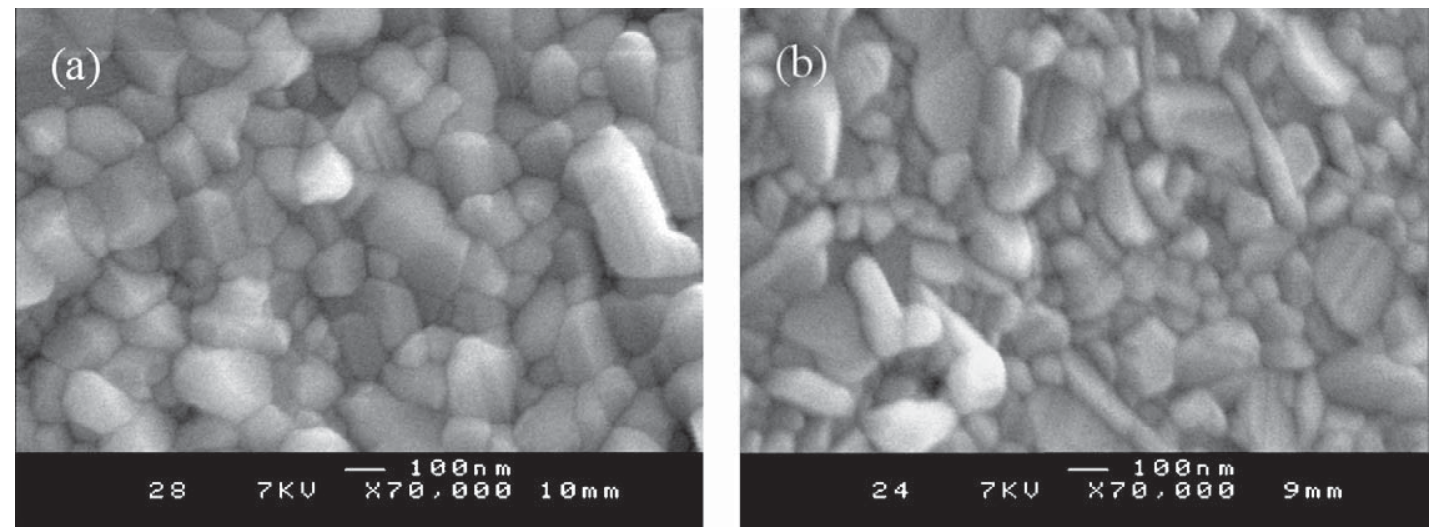

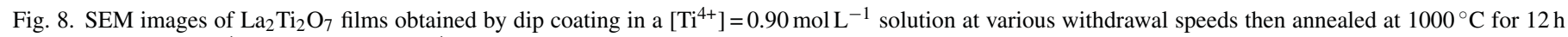
in air: (a) $40 \mathrm{~mm} \mathrm{~min}^{-1}$ and (b) $80 \mathrm{~mm} \mathrm{~min}^{-1}$. 
Table 1

Parameters describing the preferential orientation along $c$-axis of $\mathrm{La}_{2} \mathrm{Ti}_{2} \mathrm{O}_{7}$, for different films.

\begin{tabular}{lcccc}
\hline$\left[\mathrm{Ti}^{4+}\right]\left(\mathrm{mol} \mathrm{L}^{-1}\right)$ & Pulling speed $\left(\mathrm{mm} \mathrm{min}^{-1}\right)$ & $f=\left(p-p_{\mathrm{o}}\right) /\left(1-p_{\mathrm{o}}\right)(\%)$ & Adherent liquid thickness $(\mu \mathrm{m})$ & $\mathrm{Amount} \mathrm{of} \mathrm{La}_{2} \mathrm{Ti}_{2} \mathrm{O}_{7} \mathrm{reactant}\left(\mu \mathrm{mol} \mathrm{cm}{ }^{-2}\right)$ \\
\hline $0.30^{\mathrm{a}}$ & 15 & - & 3.5 & $0.5 \times 10^{-1}$ \\
& 40 & - & 6.8 & $1.0 \times 10^{-1}$ \\
& 80 & 61 & 10.8 & $2.6 \times 10^{-1}$ \\
$0.90^{\mathrm{b}}$ & 120 & 46 & 14.1 & $3.0 \times 10^{-1}$ \\
& 200 & 67 & 19.9 & $3.6 \times 10^{-1}$ \\
& 40 & 28 & 7.9 & $5.7 \times 10^{-1}$ \\
\hline
\end{tabular}

${ }^{a} \mu=1.0553 \mathrm{Pas}, \rho=1055.8 \mathrm{~kg} \mathrm{~m}^{-3}$ (viscosity and volumic mass of a $1.7 \mathrm{~mol} \mathrm{~L}^{-1} \mathrm{HNO}_{3}$ solution), $\sigma=0.072 \mathrm{~J} \mathrm{~m}^{2}$ (water).

b $\mu=1.4385 \mathrm{Pas}, \rho=1166.2 \mathrm{~kg} \mathrm{~m}^{-3}$ (viscosity and volumic mass of a $5.1 \mathrm{~mol} \mathrm{~L}^{-1} \mathrm{HNO}_{3}$ solution), $\sigma=0.072 \mathrm{~J} \mathrm{~m}^{2}$ (water).

to counterbalance any $\mathrm{Bi}^{3+}$ deficiency. A second alternative was involved, based on a promising technique: SPS, performed at lower sintering temperature for short duration. ${ }^{53}$ In addition, this technique enables to reach high densities suitable for RF magnetron sputtering. Prior being sintered, a low-temperature process involving precipitation with ammonium hydroxide was developed to obtain powder with the required stoichiometry. Fig. 9a shows the XRD pattern of the powder annealed at $600^{\circ} \mathrm{C}$ exhibits a pattern which is characteristic of an Aurivillius's phase. The theoretical intensities are calculated with PowderCell software ${ }^{54}$ using the atomic parameters obtained by a Rietveld refinement of the XRD pattern of $\mathrm{Bi}_{3.25} \mathrm{La}_{0.75} \mathrm{Ti}_{3} \mathrm{O}_{12} .{ }^{45}$ Such a low temperature for crystallisation is attributed to the high homogeneity of the precipitate and its high reactivity. The XRD peaks are rather broad and according to Sherrer's law, the crystal size can be evaluated in the $25 \mathrm{~nm}$ range. After SPS performed at $750{ }^{\circ} \mathrm{C}$, the pellet was annealed at $800^{\circ} \mathrm{C}$ for $3 \mathrm{~h}$ under oxygen in order to remove the carbon layer and to re-oxidise $\mathrm{Bi}$ metal formed at the interface with the graphite matrix (Fig. 9b). The XRD pattern is again typical of a $\mathrm{Bi}(\mathrm{La})$ titanate (Fig. 9c).

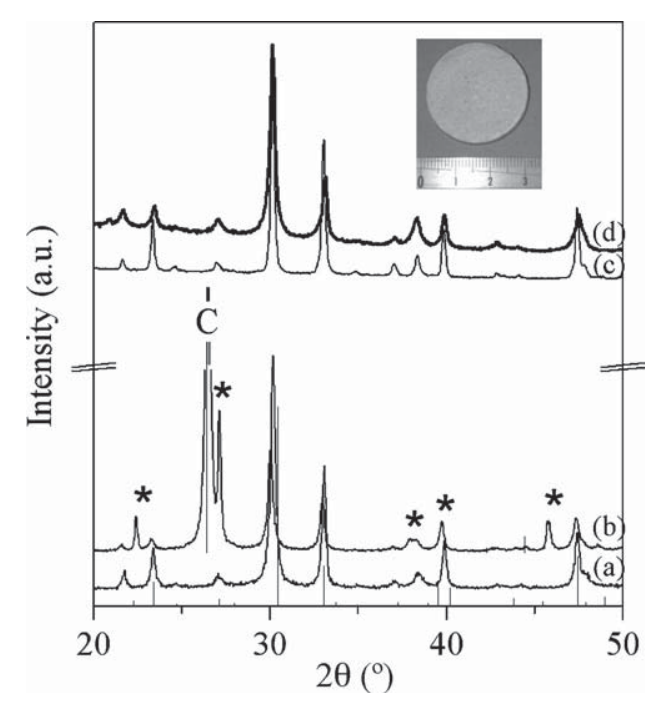

Fig. 9. XRD patterns of BLT pellet: (a) after annealing at $600^{\circ} \mathrm{C}$ for $3 \mathrm{~h}$ under air compared with theoretical intensities for BLT45 (bars), (b) after SPS compared with Bi metal (stars, according to JCPDS file no. 44-1246), C for carbon peak, (c) target annealed at $800^{\circ} \mathrm{C}$ for $3 \mathrm{~h}$ under $\mathrm{O}_{2}$ and (d) after oxidation and polishing, inset: target with the following dimensions, $3 \mathrm{~cm}$ in diameter and $0.3 \mathrm{~cm}$ thickness.
The EDX analysis reveals an average chemical composition $\mathrm{Bi}_{3.24} \mathrm{La}_{0.33}$ for $3 \mathrm{Ti}$ atoms, quite far from the required one with an important loss $\mathrm{La}_{2} \mathrm{O}_{3}$. After polishing, the average chemical composition is $3.2 \mathrm{Bi}-0.8 \mathrm{La}$ for $3 \mathrm{Ti}$ close enough to the expected one and thus suitable for RF magnetron sputtering. It is worth noting that the X-ray diffraction pattern exhibits some modifications, namely a decrease of $(h 00)$ peak intensity and a broadening of the peaks before and after polishing. The full width at half maximum (FWHM) increases from $0.25^{\circ}$ to $0.40^{\circ}$, before and after polishing, respectively. This grain growth at the interface with the electrodes can be attributed to the higher temperature reached in their vicinity during the SPS process. The target was then used to sputter BLT films on previously obtained $\mathrm{La}_{2} \mathrm{Ti}_{2} \mathrm{O}_{7}$ buffer layer oriented along $c$-axis (withdrawal speed $=120 \mathrm{~mm} \mathrm{~min}^{-1}$, less oriented but exhibiting a more homogenous surface).

Using the experimental conditions previously reported, a single PVD deposition leads, after $1 \mathrm{~h}$ ex situ annealing at $650^{\circ} \mathrm{C}$, to a $230 \mathrm{~nm}$ thick BLT film, as revealed by the X-ray diffraction pattern (Fig. 10a) and the cross-view SEM image (Fig. 10b). The SEM image (Fig. 10c) shows a film surface with a grain size ranging from 20 to $80 \mathrm{~nm}$. A further annealing for $3 \mathrm{~h}$ of this film leads to a grain growth up to $150 \mathrm{~nm}$ (Fig. 10f). In an attempt to increase the thickness of the ferroelectric layer, a second deposition was performed in the same experimental conditions. As expected, the thickness is increased up to $500 \mathrm{~nm}$ (Fig. 10e) and a good adhesion occurs between the two BLT layers: no evidence for a separation between both depositions is observed. A second $3 \mathrm{~h}$ annealing did not promote further grain growth but led to a surface with melted aspect which seems to extend under the surface. Nevertheless, after annealing, the X-ray diffraction patterns are characteristic of an Aurivillius's phase. By comparison with the theoretical intensities, all BLT films deposited on LTO buffer layers present a significant enhancement of the (2 00 ) reflection (Fig. 10d).

Thus, this preliminary study gives additional evidence that a one-step deposition process is not suitable, in our experimental conditions, to obtain an oriented BLT film, even after ex situ annealing at $650{ }^{\circ} \mathrm{C}$. A two-step process, with an intermediate and a final thermal treatment, as recently published, leads to a better orientation of the BLT films. In addition, a longer annealing period induces a further crystallisation process which is prejudicial to the expected ( $\left.\begin{array}{lll}0 & 1 & 1\end{array}\right)$ orientation of the BLT layer on the preferential [0 01 1] LTO. These results need to be further 


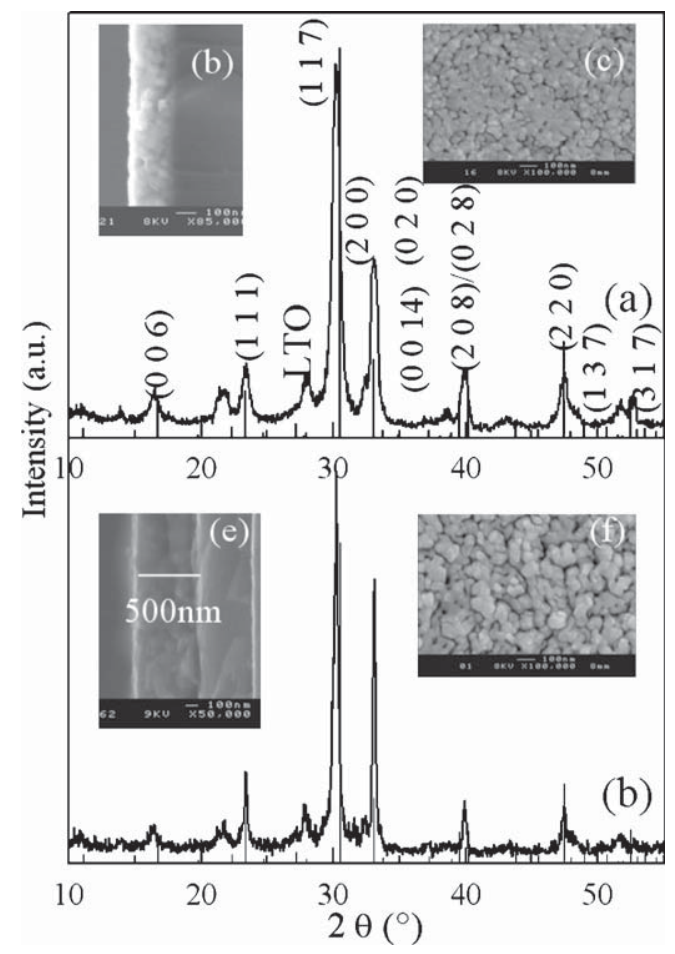

Fig. 10. X-ray diffraction patterns of a BLT film sputtered on an oriented LTO buffer layer, on Si substrate, comparison with the calculated intensity of BLT45: (a) one deposition annealed for $1 \mathrm{~h}$ at $650^{\circ} \mathrm{C}$, and corresponding SEM images, (b) cross- and (c) plane views, (d) two depositions annealed for $1 \mathrm{~h}$ and then $3 \mathrm{~h}$ at $650^{\circ} \mathrm{C}$, and corresponding SEM images, (e) cross- and (f) plane views.

investigated to understand more deeply the parameters which favour the preferential orientations both of LTO and BLT layers. To get more insight on the effect of the two-step process, HRTEM investigations are under progress.

\section{Conclusions}

An alternative route to the preparation of titanates without involving organo-metallic precursors has been developed. The dipping solution was prepared by dissolution in nitric acid of a freshly $\mathrm{TiO}_{2} \cdot n \mathrm{H}_{2} \mathrm{O}$ precipitate with the required amount of $\mathrm{La}$ nitrate is added. A uniform film was obtained by dip coating in the nitric acid solution. For a given concentration, the withdrawal speed can be optimised to favour a preferential orientation. The amount of available reactants on the substrate was optimised though the concentration of the solution and the withdrawal speed. LTO films with $c$-axis orientation were obtained and used as first buffer layer to favour the deposition of [1 00$]$ oriented BLT films. Such a buffer layer exhibiting crystallographic features equivalent to a $\left(\begin{array}{lll}1 & 1 & 0\end{array}\right)$ perovskite plane was used to favour the preferential growth of $\mathrm{Bi}_{3.25} \mathrm{La}_{0.75} \mathrm{Ti}_{3} \mathrm{O}_{12}$ layers along $a$ axis. The target of such a complex chemical composition-like $\mathrm{Bi}_{3.25} \mathrm{La}_{0.75} \mathrm{Ti}_{3} \mathrm{O}_{12}$ was successfully sintered by SPS at $750^{\circ} \mathrm{C}$. Last, involving a two-step RF magnetron sputtering process at low $\mathrm{O}_{2}$ content, high pressure and low RF power, including an intermediate and a final thermal treatment at low temperature $\left(650^{\circ} \mathrm{C}\right.$, for $1 \mathrm{~h}$ ), we succeed to deposit well crystallised BLT layers exhibiting a preferential orientation along [ 1000$]$. These preliminary results obtained on $\mathrm{Si}$ substrates are very promising for further applications. Same deposition process is currently investigated on multi-layer structures including bottom and top Pt electrodes. Electrical measurements will be finally performed to control the effect on BLT layer polarisation and its ferroelectric response.

\section{Acknowledgments}

The authors are deeply indebted to Alain Barrault at the service commun de microscopie électronique à balayage for his assistance in recording SEM images and to Eric Gautron for TEM cross-section preparation. In addition, Pierre Barroy, Nicolas Leclair and Marc Souilhat are acknowledged for target preparation and analysis.

\section{References}

1. Park, B. H., Kang, B. S., Bu, S. D., Noh, T. W., Lee, J. and Jo, W., Lanthanumsubstituted bismuth titanate for use in non-volatile memories. Nature, 1999, 401, 682.

2. Chu, M.-W., Ganne, M., Caldes, M. T., Gautier, E. and Brohan, L., X-ray photoemission spectroscopy characterization of the electrode-ferroelectric interfaces in $\mathrm{Pt} / \mathrm{Bi}_{4} \mathrm{Ti}_{3} \mathrm{O}_{12} / \mathrm{Pt}$ and $\mathrm{Pt} / \mathrm{Bi}_{3.25} \mathrm{La}_{0.75} \mathrm{Ti}_{3} \mathrm{O}_{12} / \mathrm{Pt}$ capacitors: possible influence of defect structure on fatigue properties. Phys. Rev. B, 2003, 68(1), 014102/1-014102/11.

3. Chu, M.-W., Lee, S. K., Hesse, D. and Gösele, U., $90^{\circ}$ a-b domains in epitaxial ferroelectric $\mathrm{Bi}_{3.25} \mathrm{La}_{0.75} \mathrm{Ti}_{3} \mathrm{O}_{12}$ films. Appl. Phys. Lett., 2004, 85, 2029-2031.

4. Cummins, S. E. and Cross, L. E., Electrical and optical properties of ferroelectric single crystals. J. Appl. Phys., 1968, 39, 2268.

5. Takenaka, T. and Sanaka, K., Grain orientation and electrical properties of hot-forged bismuth titanium oxide $\mathrm{Bi}_{4} \mathrm{Ti}_{3} \mathrm{O}_{12}$ ceramics. Jpn. J. Appl. Phys., 1980, 19, 31-39.

6. Ramesh, R., Luther, K., Wilkens, B., Hart, D. L., Wang, E., Tarascon, J. M. et al., Epitaxial growth of ferroelectric bismuth titanate thin films by pulsed laser deposition. Appl. Phys. Lett., 1990, 57, 1505.

7. Esaki, H., Quantum jump and "Kaizen" toward commercialization of ferroelectric ULSI memories. Integr. Ferroelectr., 1997, 14(1-4), 11-21.

8. Lee, H. N. and Hesse, D., Anisotropic ferroelectric properties of epitaxially twinned $\mathrm{Bi}_{3.25} \mathrm{La}_{0} .75 \mathrm{Ti}_{3} \mathrm{O}_{12}$ thin films grown with three different orientations. Appl. Phys. Lett., 2002, 80(6), 1040.

9. Lee, H. N., Hesse, D., Zakharov, N., Lee, S. K. and Gosele, U., Growth of uniformly a-axis-oriented ferroelectric lanthanum-substituted bismuth titanate films on silicon substrates. J. Appl. Phys., 2003, 93(9), 5592.

10. Harp, G. R., Farrow, R. F. C., Marks, R. F. and Vazquez, J. E., Epitaxial growth and homoepitaxy of platinum (1 110$)$ and copper (1 110$)$ on strontium titanate (1 10 ). J. Cryst. Growth, 1993, 127, 627.

11. Nanot, M., Queyroux, F. and Gilles, J.-C., Formation and stability of $\mathrm{A}_{n} \mathrm{~B}_{n} \mathrm{O}_{3 n+2}$ phases exemplified in lanthanum titanate $\mathrm{La}_{2} \mathrm{Ti}_{2} \mathrm{O}_{7}$-calcium titanate(IV), neodymium titanate $\mathrm{Nd}_{2} \mathrm{Ti}_{2} \mathrm{O}_{7}$-calcium titanate(IV) and calcium niobate $\mathrm{Ca}_{2} \mathrm{Nb}_{2} \mathrm{O}_{7}$-calcium titanate(IV) systems. Mater. Res. Bull., 1977, 12(9), 915-922.

12. Schmalle, H. W., Williams, T., Reller, A., Linden, A. and Bednorz, J. G., The twin structure of lanthanum titanium oxide $\mathrm{La}_{2} \mathrm{Ti}_{2} \mathrm{O}_{7}$ : X-ray and transmission electron microscopy studies. Acta Cryst. B, 1993, 49, 235-244.

13. Nanamatsu, S., Kimura, M., Doi, K., Matsushita, S. and Yamada, N., New ferroelectric lanthanum titanate $\mathrm{La}_{2} \mathrm{Ti}_{2} \mathrm{O}_{7}$. Ferroelectrics, 1974, 8, 511.

14. Kimura, M., Nanamatsu, S., Doi, K., Matsushita, S. and Yamada, N., Electrooptic and piezoelectric properties of $\mathrm{La}_{2} \mathrm{Ti}_{2} \mathrm{O}_{7}$ single crystal. Jpn. J. Appl. Phys., 1972, 11, 904.

15. Skapin, S. D., Kolar, D. and Suvorov, D., Phase stability and equilibria in the $\mathrm{La}_{2} \mathrm{O}_{3}-\mathrm{TiO}_{2}$ system. J. Eur. Ceram. Soc., 2000, 20(8), 1179-1185. 
16. Arney, D., Porter, B., Greve, B. and Maggard, P. A., New molten-salt synthesis and photocatalytic properties of $\mathrm{La}_{2} \mathrm{Ti}_{2} \mathrm{O}_{7}$ particles. J. Photochem. Photobiol. A: Chem., 2008, 199(2-3), 230-235.

17. Shcherbakova, L. G., Mamsurova, L. G. and Sukhanova, G. E., Rare earth element titanates. Russ. Chem. Rev., 1979, 48, 423-447.

18. Takahashi, J. and Otsuka, T., Vibrational spectroscopic study of structural evolution in the coprecipitated precursors to lanthanum tin oxide $\mathrm{La}_{2} \mathrm{Sn}_{2} \mathrm{O}_{7}$ and lanthanum titanium oxide $\mathrm{La}_{2} \mathrm{Ti}_{2} \mathrm{O}_{7}$. J. Am. Ceram. Soc., 1989, 72, 426.

19. Suresh, M., Prasadarao, A. V. and Komarneni, S., Mixed hydroxide precursors for $\mathrm{La}_{2} \mathrm{Ti}_{2} \mathrm{O}_{7}$ and $\mathrm{Nd}_{2} \mathrm{Ti}_{2} \mathrm{O}_{7}$ by homogeneous precipitation. $J$. Electroceram., 2001, 6(2), 147-151.

20. Chen, D. and $\mathrm{Xu}, \mathrm{R}$., Hydrothermal synthesis and characterization of $\mathrm{La}_{2} \mathrm{M}_{2} \mathrm{O}_{7}(\mathrm{M}=\mathrm{Ti}, \mathrm{Zr})$ powders. Mater. Res. Bull., 1998, 33(3), 409-417.

21. Song, H., Peng, T., Cai, P., Yi, H. and Yan, C., Hydrothermal synthesis of flaky crystallized $\mathrm{La}_{2} \mathrm{Ti}_{2} \mathrm{O}_{7}$ for producing hydrogen from photocatalytic water splitting. Catal. Lett., 2007, 113(1-2), 54-58.

22. Li, K. W., Wang, Y., Wang, H., Zhu, M. and Yan, H., Hydrothermal synthesis and photocatalytic properties of layered $\mathrm{La}_{2} \mathrm{Ti}_{2} \mathrm{O}_{7}$ nanosheets. Nanotechnology, 2006, 17(19), 4863-4867.

23. Milanova, M. M., Kakihana, M., Arima, M., Yashima, M. and Yoshimura, M., A simple solution route to the synthesis of pure $\mathrm{La}_{2} \mathrm{Ti}_{2} \mathrm{O}_{7}$ and $\mathrm{Nd}_{2} \mathrm{Ti}_{2} \mathrm{O}_{7}$ at $700-800{ }^{\circ} \mathrm{C}$ by polymerized complex method. J. Alloys Compd., 1996, 242(1-2), 6-10.

24. Milanova, M. M., Arnaudov, M. G., Getsova, M. M. and Todorovsky, D. S., Preparation and characterization of solid-state lanthanum-titanium citrate complexes. J. Alloys Compd., 1998, 264(1-2), 95-103.

25. Kim, H. G., Hwang, D. H., Bae, S. W., Jung, J. H. and Lee, J. S., Photocatalytic water splitting over $\mathrm{La}_{2} \mathrm{Ti}_{2} \mathrm{O}_{7}$ synthesized by the polymerizable complex method. Catal. Lett., 2003, 91(3-4), 193-198.

26. Todorovsky, D. S., Getsova, M. M., Wawer, I., Stefanov, P. and Enchev, V., On the chemical nature of lanthanum-titanium citric complexes, precursors of $\mathrm{La}_{2} \mathrm{Ti}_{2} \mathrm{O}_{7}$. Mater. Lett., 2004, 58(27-28), 3559-3563.

27. Todorovsky, D. S., Getsova, M. M., Milanova, M. M., Kakihana, M., Petrova, N. L., Arnaudov, M. G. et al., The chemistry of the processes involved in the production of lanthanide titanates by the polymerized-complex method. Can. J. Chem., 2007, 85(7-8), 547-559.

28. Li, Z., Chen, G., Tian, X. and Li, Y., Photocatalytic property of $\mathrm{La}_{2} \mathrm{Ti}_{2} \mathrm{O}_{7}$ synthesized by the mineralization polymerizable complex method. Mater. Res. Bull., 2008, 43(7), 1781-1788.

29. Prasadarao, A. V., Selvaraj, U., Komarneni, S. and Bhalla, A. S., Grain orientation in sol-gel derived $\mathrm{Ln}_{2} \mathrm{Ti}_{2} \mathrm{O}_{7}$ ceramics $(\mathrm{Ln}=\mathrm{La}, \mathrm{Nd})$. Mater. Lett., 1991, 12(5), 306-310.

30. Prasadarao, A. V., Selvaraj, U., Komarneni, S. and Bhalla, A. S., Sol-gel synthesis of $\mathrm{Ln}_{2}(\mathrm{Ln}=\mathrm{La}, \mathrm{Nd}) \mathrm{Ti}_{2} \mathrm{O}_{7}$. J. Mater. Res., 1992, 7(10), 2859-2863.

31. Zhao, Z., Zhang, Y., Yang, J., Li, H., Song, W. and Zhao, X., Low-temperature synthesis of $\mathrm{La}_{2} \mathrm{Ti}_{2} \mathrm{O}_{7}$ nanocrystal by metalorganic decomposition method. J. Ceram. Soc. Jpn., 2005, 113, 67-70.

32. Prasadarao, A. V., Selvaraj, U., Komarneni, S. and Bhalla, A. S., Fabrication of lanthanum titanate $\left(\mathrm{La}_{2} \mathrm{Ti}_{2} \mathrm{O}_{7}\right)$ thin films by a sol-gel. Ferroelectrics, 1992, 14(3-4), 65-72.

33. Jeon, S. J., Cho, K. H., Nam, H.-D., Park, C. W., Jang, S. W. and Lee, H. Y., Crystallization and dielectric properties of lanthanum titanate thin films by metalorganic decomposition. J. Korean Phys. Soc., 1998, 32, S1657-S1659.

34. Sik, K. W., Ha, S.-M., Yun, S. and Park, H.-H., Microstructure and electrical properties of $\mathrm{Ln}_{2} \mathrm{Ti}_{2} \mathrm{O}_{7}(\mathrm{Ln}=\mathrm{La}, \mathrm{Nd})$. Thin Solid Films, 2002, 420-421, 575-578.
35. Sandstrom, M. M. and Fuierer, P., Sol-gel synthesis of textured lanthanum titanate thin films. J. Mater. Res., 2003, 18(2), 357-362.

36. Li, A.-D., Wang, Y.-J., Huang, S., Cheng, J.-B., Wu, D. and Ming, N.B., Effect of in situ applied electric field on the growth of $\mathrm{La}_{2} \mathrm{Ti}_{2} \mathrm{O}_{7}$ thin films by chemical solution deposition. J. Cryst. Growth, 2004, 268(1-2), 198-203.

37. Kushkov, V. D., Zverlin, A. V., Zaslavskii, A. M., Slivinskaya, A. E. and Melnikov, A. V., Structure of the lanthanide titanium oxide $\mathrm{Ln}_{2} \mathrm{Ti}_{2} \mathrm{O}_{7}$ thin films prepared by pulsed-laser evaporation. J. Mater. Sci., 1993, 28(2), 361-363.

38. Dickerson, B. D., Nagata, M., Song, Y. J., Nam, H. D. and Desu, S. B., Spectroscopic ellipsometry characterization of $\mathrm{La}_{2} \mathrm{Ti}_{2} \mathrm{O}_{7}$ thin films. Mater. Res. Soc. Symp. Proc., 1995, 361, 197-202.

39. Ohtomo, A., Muller, D. A., Grazul, J. L. and Hwang, H. Y., Epitaxial growth and electronic structure of $\mathrm{LaTiO}_{x}$ films. Appl. Phys. Lett., 2002, 80(21), 3922-3924.

40. Kim, K. H., Norton, D. P., Budai, J. D., Chisholm, M. F., Sales, B. C., Christen, D. K. et al., Epitaxial structure and transport in $\mathrm{LaTiO}_{3+x}$ films on (0 01 1) $\mathrm{SrTiO}_{3}$. Phys. Stat. Solid. A: Appl. Res., 2003, 200(2), 346-351.

41. Delage, T., Champeaux, C., Catherinot, A., Seaux, J.-F., Madrangeas, V. and Cros, D., High-k BST films deposited on MgO by PLD with and without buffer-layer. Thin Solid Films, 2004, 453-454, 279-284.

42. Wu, C. M. and Wu, T. B., Low temperature deposition of $\mathrm{Ba}_{0.4} \mathrm{Sr}_{0.6} \mathrm{TiO}_{3}$ thin films on $\mathrm{LaNiO}_{3}$-buffered electrode by RF magnetron sputtering. Mater Lett., 1997, 33, 97-100.

43. Cukauskas, E. J., Kirchoefer, S. W. and Chang, W., Morphology and dielectric properties of $\mathrm{Ba}_{0.5} \mathrm{Sr}_{0.5} \mathrm{TiO}_{3}$ thin films on annealed $\left(\begin{array}{lll}1 & 0 & 0\end{array}\right) \mathrm{MgO}$. J. Cryst. Growth, 2002, 236, 239-247.

44. Besland, M.-P., Djani-Ait Aissa, H., Barroy, P. R. J., Lafane, S., Tessier, P.-Y., Angleraud, B. et al., Comparison of lanthanum substituted bismuth titanate (BLT) thin films deposited by sputtering and pulsed laser deposition Thin Solid Films, 2006, 495, 86-91.

45. Wen, C. M., PhD thesis of the university of Nantes, 2002.

46. Liu, C.-E., Richard-Plouet, M., Albertini, D., Besland, M.-P. and Brohan, $\mathrm{L}$., $\mathrm{Bi}_{3.25} \mathrm{La}_{0.75} \mathrm{Ti}_{3} \mathrm{O}_{12}$ films on $\mathrm{La}_{2} \mathrm{Ti}_{2} \mathrm{O}_{7}$ thin films prepared by chemical solution deposition. J. Phys: Conf. Series, 2008, 94, 012014.

47. Besland, M.-P., Borderon, C., Barroy, P. R. J., Le Tacon, S., Richard-Plouet, M., Averty, D. et al., Improvement of dielectric properties of BLT thin films deposited by magnetron sputtering. J. Phys. Conf. Series, 2008, 94, 012006.

48. Lotgering, F. K., Topotactical reactions with ferrimagnetic oxides having hexagonal crystal structures. Int. J. Inorg. Nucl. Chem., 1959, 9, 113-123.

49. Gobichon, A.-E., Auffrédic, J.-P. and Louër, D., Thermal decomposition of neutral and basic lanthanum nitrates studied with temperature-dependent powder diffraction and thermogravimetric analysis. Solid State Ionics, 1996, 93, 51-64.

50. Landau, L. and Levich, B., Acta Physicochim. URSS, 1942, 17, 42-54.

51. Benbertal, D., Mosset, A. and Trombe, J. C., Synthesis and crystal structure of a new lanthanum and titanium silicate. Mater. Res. Bull., 1994, 29, 47-54.

52. Drache, M., Huve, M., Roussel, P. and Conflant, P., Polymorphism of $\mathrm{Bi}_{1-x} \operatorname{Ln}_{x} \mathrm{O}_{1} .5$ phases $(0<x<0.40)$. Characterization of a new compound $\mathrm{Bi}_{4} \mathrm{Ln}_{2} \mathrm{O}_{9}(x=0.33 ; \mathrm{Ln}=\mathrm{La}, \mathrm{Pr}, \mathrm{Nd})$. Mater. Res. Bull., 2003, 38, 113.

53. Omori, M., Principles and Mechanisms of the SPS Process. What's, SPS, SPS SYNTEX Inc. Mater. Sci. Eng. A, 287 (2000), 183, http://www.scmsps.com/e_htm/whatsps_e_htm/whatsps4_e.htm.

54. Kraus, W. and Nolze, G., PowderCell 2.4, www.ccp14.ac.uk/tutorial/ powdcell/index.html. 